\title{
Switching from a GnRH agonist to a GnRH antagonist in prostate cancer patients: A systematic review and meta-analysis
}

\author{
Kaleem S. Atchia ${ }^{1}$; Christopher J.D. Wallis ${ }^{2}$; Neil Fleshner ${ }^{2}$; Paul Toren ${ }^{1}$ \\ ${ }^{1}$ Department of Surgery, Faculty of Medicine, Université Laval; Centre Hospitalier Universitaire (CHU) de Québec \\ Research Centre, Oncology Division, Quebec City, QC, Canada; ${ }^{2}$ Department of Surgery, Faculty of Medicine, \\ University of Toronto, Toronto, ON, Canada
}

Funding: Funding for statistical analyses was provided by Ferring Pharmaceuticals. Dr. Toren is supported by a clinician-scientist award from Fonds de Recherche du Québec - Santé (\#32774).

Acknowledgements: The authors thank Sergio Della Nora (Medical Director - Urology, Ferring Pharmaceuticals) for having reviewed the manuscript.

Cite as: Can Urol Assoc J 2019 July 23; Epub ahead of print. http://dx.doi.org/10.5489/cuaj.5996

Published online July 23, 2019

$* * *$

\section{Abstract}

Introduction: We sought to address whether there are clinical responses when patients who are failing gonadotropin releasing hormone (GnRH) agonist therapy are switched to degarelix. Androgen-deprivation therapy remains the backbone of treatment for disseminated prostate cancer and may be achieved with orchiectomy, GnRH agonists, or degarelix, a GnRH antagonist. Methods: To perform a systematic review and meta-analysis, a search of the BIOSIS Previews, Embase, International Pharmaceutical Abstracts, MEDLINE, and Google Scholar databases was performed using key terms. Quantitative meta-analysis was performed to provide a pooled estimate of prostate specific antigen (PSA) response at three months.

Results: Thirteen studies were identified, eight of which were included in the qualitative and quantitative analyses. Patient characteristics were broadly similar between the studies. Out of 155 patients across all included studies, 20 had stable PSA after the switch (12.9\%), 14 had between 10-30\% decrease in PSA (9.0\%), three had between 30-50\% decrease (1.9\%), and 13 had more than $50 \%$ decrease (8.4\%). Random effects meta-analysis of these data demonstrated a pooled response rate of 27.75 (95\% confidence interval 18.9-36.5\%; $\mathrm{I}^{2}=7.9 \%$ ). Changes in testosterone levels following the switch could not be quantitatively assessed due to lack of sufficient data. 
Conclusions: Our results suggest that a switch to GnRH antagonist following progression on a GnRH agonist may result in a stable or decreased PSA at three months in about $30 \%$ of patients. This information should be considered among the potential options to discuss with patients with a rising PSA on GnRH agonist therapy.

\section{Introduction}

The backbone of treatment for patients with newly diagnosed metastatic hormone-sensitive prostate cancer is androgen deprivation therapy (ADT). Bilateral orchiectomy remains an economical option, but for psychological and other reasons, medical therapy is often preferred. Both gonadotropin-releasing hormone $(\mathrm{GnRH})$ agonists and antagonists are utilised for ADT, with $\mathrm{GnRH}$ agonists being most widely used as first-line treatment. Although effective, patients eventually develop resistance to GnRH agonists, including the development of castrationresistant prostate cancer (CRPC).

Upon disease progression to CRPC, more potent therapies such as abiraterone plus prednisone, enzalutamide, and docetaxel are available. However, these engender more side effects and much higher costs. GnRH antagonists, such as degarelix, have been shown to be equivalent in efficacy to the GnRH agonist leuprolide. ${ }^{1}$ In addition to rapid testosterone suppression and lower follicle-stimulating hormone (FSH) levels, some data suggest better treatment response in terms of overall survival ${ }^{2}$ and PSA progression-free survival with degarelix. ${ }^{3}$ However, evidence regarding whether, upon resistance to GnRH agonist, a switch to GnRH antagonists could represent a second-line treatment in ADT for patients prior to starting potent CRPC treatment agents is thus far limited to case reports and case series.

Current clinical guidelines do not recognize the possibility of switching to GnRH antagonists as treatment after PSA progression on a GnRH agonist, though a switch may be considered when testosterone levels are incompletely suppressed. ${ }^{4,5}$ The use of a GnRH agonist to antagonist switch at time to PSA progression has several potential advantages. It may delay the introduction of more potent side effects of first-line CRPC agents. Similarly, it has potential to decrease treatment costs by delaying the introduction of these costlier agents. However, the efficacy of this switch from GnRH agonist to antagonist for patients progressing on ADT is yet unproven.

The objective of our study was to perform a systematic review and meta-analysis evaluating the efficacy of switching from a GnRH agonist to a GnRH antagonist. Our results present a pooled estimate of the PSA response to a GnRH agonist to antagonist switch from all reported studies and will facilitate better patient counseling and shared decision making with regards to this treatment option. 


\section{Methods}

\section{Research question}

We defined our central research question as the following: Do prostate cancer patients treated with GnRH agonist who have clinical, biochemical or radiological progression on ADT respond to a switch to degarelix, a GnRH antagonist?

\section{Types of studies}

We include in our analysis all patients on ADT for metastatic or recurrent prostate cancer. Progression of disease on GnRH therapy was defined as a rising PSA or appearance of new metastases on imaging despite standard, regular GnRH agonist dosing. We focus on degarelix as it is the only currently available GnRH antagonist for prostate cancer patients, except in Germany where abarelix is available. Both prospective and retrospective observational studies were included as well as case reports. Both published papers and abstracts, where sufficient detail existed to confirm patient characteristics and results, were included. Studies with less than 3 months follow-up were excluded.

\section{Types of participants and exposure}

Patients included had prostate cancer with or without distant metastases for which ADT was deemed indicated by the treating physician. Dosing of the GnRH agonist was according to the agent prescribed and information on testosterone levels was collected when reported. The definition of a rising PSA on GnRH was not strict for inclusion in our analysis, but generally expected to encompass recommendations from the PCWG3 guidelines. ${ }^{6}$ A minimum follow-up of at least three months following a switch to degarelix was required. Dosing of degarelix was typically $240 \mathrm{mg}$ initially, followed by monthly maintenance doses of $80 \mathrm{mg}$; however, the loading dose was not required for study inclusion. Studies were included irrespective of the serum PSA or testosterone at the switch, the duration of prior GnRH agonist treatment, GnRH agonist formulation or the number of prior treatment options.

\section{Outcome measures}

The primary outcome was the PSA response rate. For the quantitative meta-analysis, a response was defined as stable or decreasing PSA at three months following the switch from a GnRH agonist to degarelix. For the qualitative analysis, we also examined the degree of PSA response where stability is defined as $\leq 10 \%$ variation and decreasing PSA is either $>10 \%,>30 \%$ or $>50 \%$ reduction. We further planned to assess changes reported in castrate testosterone levels as a secondary outcome.

\section{Literature review and search strategy}

The Preferred Reporting Items for Systematic Reviews and Meta-Analyses (PRISMA) was used in reporting this systematic review and meta-analysis. ${ }^{7}$ To identify reports to address our 
research question, a search of the BIOSIS Previews, Embase, International Pharmaceutical Abstracts, MEDLINE and Google Scholar databases was performed. Search terms used included "gonadotropin-releasing hormone agonist", "gonadotropin-releasing hormone antagonist" with related terms and individual drug names, prostate cancer, switch and related terms. For each relevant article identified, references were hand-searched as well as all related papers linked on the Pubmed portal.

Selection of studies was performed by P.T.. Titles, abstracts and, where necessary, fulltext review was used to determine if each study met inclusion and exclusion criteria. The final list of studies selected was agreed upon by P.T. and N.F. The data extraction of study characteristics and outcome measures was performed by K.S.A. with independent verification by other authors.

\section{Statistical analysis}

Based on the identified literature following systematic review, quantitative meta-analysis was performed to provide a pooled estimate of the proportion of patients with any response three months following a switch from a GnRH agonist to degarelix. Due to clinical heterogeneity among the included studies, we utilized random effects models using the procedure of Neyeloff, Fuchs, and Moreira. ${ }^{8}$ Data are presented as the proportion of responders at 3 months with $95 \%$ confidence interval. We quantified heterogeneity using $\mathrm{I}^{2}$ values. ${ }^{9}$ To assess for publication bias, we planned to use funnel plots for all outcomes with 10 or more included studies.

\section{Results}

Following our literature review, 13 studies were identified and after review, 8 were included in the qualitative and quantitative analyses, representing a total of 155 patients (Supp. Figure 1). Studies that used GnRH antagonists other than degarelix, such as abarelix $(n=2)$, or that switched therapies other than upon PSA progression $(n=2)$, were excluded. A case report that had data only for one month following the switch was also excluded. In total, 5 prospective studies, 2 retrospective studies and 1 case report were included.

Patient characteristics were broadly similar between the studies included in this metaanalysis. The groups studied comprised mainly older patients with advanced or metastatic prostate cancer from North America, Europe or Japan. Most of the patients had a Gleason score above 6 and some had undergone prior local therapy in the form of either radical prostatectomy or radiation therapy. Patients who had undergone chemotherapy before the switch were included in one study. ${ }^{10}$ Some studies comprised only or included patients treated with complete androgen blockade (ADT plus an anti-androgen) ${ }^{11-15}$ while others included patients with ADT alone before the switch. ${ }^{16,17}$ However, all published studies described excluding the possibility of antiandrogen withdrawal syndrome. Patients were mostly treated with either leuprolide or goserelin for at least 12 months before PSA progression and at least 93\% of patients (144/155) had 
castrate-level testosterone ( $<0.5 \mathrm{ng} / \mathrm{mL}$ ) before the switch to degarelix. Baseline patient characteristics of the included studies are summarized in Tables 1 and 2.

All studies utilised PSA response as the main outcome of clinical assessment reported following a switch to degarelix. Based on reported results and qualitative assessment of individual patient data, out of 155 patients across all included studies, 20 had stable PSA after the switch (12.9\%), 14 had between 10-30\% decrease in PSA (9.0\%), 3 had between 30-50\% decrease (1.9\%) and 13 had more than 50\% decrease (8.4\%). A summary of PSA responses in the selected studies is presented in Table 3. From this data, the range of any PSA response at 3 months after the switch was 14 to $100 \%$. Random effects meta-analysis of these data demonstrated a pooled response rate of 27.75 (95\% confidence interval 18.9-36.5\%; $\mathrm{I}^{2}=7.9 \%$ ) (Supp. Table 1; Figure 1).

Some studies determined that overall, there was no statistically significant difference between PSA levels before and after the switch. ${ }^{10,12}$ These studies also found no correlation between initial PSA levels and response to the switch. Furthermore, out of 24 patients with PSA response in the studies that reported follow-up data beyond the evaluation 3 months after the switch, 16 had no PSA progression during follow-up (mean[range] : 9.5 months [5-20]), 7 had PSA progression (4.83 months [4-7]) and 2 switched therapies or withdrew from the trial. ${ }^{11,14-16}$

Changes in testosterone levels following the switch to degarelix could not be quantitatively assessed due to lack of sufficient individual data for analysis. When this detail was available, most patients across the included studies showed no significant difference in testosterone levels and maintained castrate levels of testosterone after the switch. On the other hand, several studies found that FSH level decreased further in many patients after the switch, although decreases were not necessarily associated with a PSA response. ${ }^{10,11,14}$

\section{Discussion}

Our systematic review and meta-analysis suggest that the switch to degarelix following failure of GnRH agonist therapy results in a PSA response at 3 months in almost $30 \%$ of patients with predominantly advanced or resistant prostate cancer. With varied reports and relatively few identified studies, this provides a useful estimate for clinicians to consider and discuss this option with patients who are progressing on ADT. To date, this represents the most comprehensive analysis of this topic and remains highly pertinent as layering and sequencing of treatments for CRPC is rapidly evolving.

Prior to the current era of potent AR antagonists, manoeuvres for patients progressing on ADT have previously been evaluated. Escalation of bicalutamide dose to $150 \mathrm{mg}$ resulted in a PSA response at 12 months of $22 \%$ in a Phase II Canadian study. ${ }^{18}$ Moreover, the option of antiandrogen withdrawal may still be considered in patients who are taking concomitant bicalutamide. However, newer agents demonstrate superior treatment responses in nonmetastatic patients. In the TERRAIN study the median time to PSA progression was 19.4 months with enzalutamide versus 5.8 months with bicalutamide, ${ }^{19}$ with even more impressive 
differences between apalutamide or enzalutamide and placebo in the SPARTAN ${ }^{20}$ and PROSPER $^{21}$ studies, respectively. The use of a GnRH agonist to antagonist switch permits sequential layering of ADT with these newer agents. Moreover, for patients and healthcare systems around the world with limited ability to pay for newer agents, this therapeutic option could also have economic value.

Two mechanisms potentially contributing to the PSA response with degarelix after failure on a GnRH agonist include a more profound decrease in testosterone and a decrease in serum FSH levels. ${ }^{22}$ Prior studies suggest achieving and maintaining castrate-level testosterone with GnRH agonists is associated with longer duration of response to ADT. ${ }^{23}$ However, our systematic review and meta-analysis did not support significant differences in testosterone levels after the switch. Moreover, a prior randomized study of degarelix subsequent to one year of leuprolide did not show decreases in serum testosterone. ${ }^{3}$ In the same study and others, FSH levels have been shown to be further reduced with GnRH antagonists after orchiectomy ${ }^{24}$ or GnRH agonist therapy ${ }^{25-27}$. The significance of FSH in prostate cancer is still under investigation, with one study indicating the FSH receptor is overexpressed in prostate cancer metastases ${ }^{28}$ and another suggesting a link to the development of CRPC. ${ }^{29}$ In this meta-analysis, studies by Miller et al. ${ }^{14}$ and Ezaki et al. ${ }^{10}$ demonstrated significantly decreased FSH levels after the switch to degarelix, while Fukui et al. did not. ${ }^{11}$ FSH reductions were also observed in patients with no PSA response. ${ }^{10,11,14}$ Therefore, the contribution of reduced FSH signalling in achieving a PSA response is possible but remains to be further explored.

Our study has limitations which need to be considered. Despite a broad search of both abstracts and published papers, the number of studies identified was low. Given the nature of the literature available on this subject, there is a high potential for publication bias. Moreover, the assessed timepoint in the reported studies remains relatively short with most being around 3 months with few long-term follow-ups. Additionally, it is unclear whether PSA responses at 3 months represent a meaningful endpoint for patient outcomes. Accordingly, prior studies of antiandrogen withdrawal found PSA responses at 3-6 months, but not measurable differences in long-term outcomes. ${ }^{30}$ Given the results available in the identified studies on changes in testosterone levels after the switch, this secondary outcome could not be included in the analysis to provide a useful estimate for clinicians. Lastly, the small sample size as well as the lack of control groups and randomised controlled trials within this meta-analysis are limitations that emphasize the need for more studies to better define the utility of GnRH antagonists after agonist failure. 


\section{Conclusions}

Treatment decisions for prostate cancer patients on ADT need to be individualized to each patient and physician context. Our systematic review and meta-analysis suggest that a switch to GnRH antagonist following progression on a GnRH agonist may result in a stable or decreased PSA at 3 months in almost 30\% of patients. This information should be considered among the potential options to consider and discuss with patients with a rising PSA on GnRH agonist therapy. 


\section{References}

1. Klotz L, Boccon-Gibod L, Shore ND, et al. The efficacy and safety of degarelix: a 12month, comparative, randomized, open-label, parallel-group phase III study in patients with prostate cancer. BJU international 2008;102:1531-8.

2. Klotz L, Miller K, Crawford ED, et al. Disease control outcomes from analysis of pooled individual patient data from five comparative randomised clinical trials of degarelix versus luteinising hormone-releasing hormone agonists. European urology 2014;66:1101-8.

3. Crawford ED, Tombal B, Miller K, et al. A phase III extension trial with a 1-arm crossover from leuprolide to degarelix: comparison of gonadotropin-releasing hormone agonist and antagonist effect on prostate cancer. The Journal of urology 2011;186:88997.

4. Cornford P, Bellmunt J, Bolla M, et al. EAU-ESTRO-SIOG Guidelines on Prostate Cancer. Part II: Treatment of Relapsing, Metastatic, and Castration-Resistant Prostate Cancer. European urology 2017;71:630-42.

5. Lowrance WT, Murad MH, Oh WK, et al. Castration-Resistant Prostate Cancer: AUA Guideline Amendment 2018. The Journal of urology 2018;200:1264-72.

6. Scher HI, Morris MJ, Stadler WM, et al. Trial Design and Objectives for CastrationResistant Prostate Cancer: Updated Recommendations From the Prostate Cancer Clinical Trials Working Group 3. Journal of clinical oncology : official journal of the American Society of Clinical Oncology 2016;34:1402-18.

7. Moher D, Liberati A, Tetzlaff J, et al. Preferred reporting items for systematic reviews and meta-analyses: the PRISMA statement. Annals of internal medicine 2009;151:264-9, W64.

8. Neyeloff JL, Fuchs SC, Moreira LB. Meta-analyses and Forest plots using a microsoft excel spreadsheet: step-by-step guide focusing on descriptive data analysis. $B M C$ research notes 2012;5:52.

9. Higgins JP, Thompson SG, Deeks JJ, et al. Measuring inconsistency in meta-analyses. Bmj 2003;327:557-60.

10. Ezaki T, Kosaka T, Mizuno R, et al. Efficacy of treatment with a GnRH antagonist in prostate cancer patients previously treated with a GnRH agonist. Cancer chemotherapy and pharmacology 2015;76:301-6.

11. Fukui S, Nakai Y, Kagebayashi Y, et al. Switching of GnRH Agent from Agonist to Antagonist in Patients with Castration-Resistant Prostate Cancer. Open Journal of Urology 2016;6:9.

12. Masson-Lecomte A, Guy L, Pedron P, et al. A switch from GnRH agonist to GnRH antagonist in castration-resistant prostate cancer patients leads to a low response rate on PSA. World journal of urology 2013;31:339-43.

13. Soga N, Kageyama T, Ogura Y, et al. Clinical Effect of Switching from a Luteinizing Hormone-Releasing Hormone Agonist to an Antagonist in Patients with CastrationResistant Prostate Cancer and Serum Testosterone Level $>/=20 \mathrm{ng} / \mathrm{dl}$. Current urology 2016;9:31-5. 
14. Miller K, Simson G, Goble S, et al. Efficacy of degarelix in prostate cancer patients following failure on luteinizing hormone-releasing hormone agonist treatment: results from an open-label, multicentre, uncontrolled, phase II trial (CS27). Therapeutic advances in urology 2015;7:105-15.

15. Raddin RS, Walko CM, Whang YE. Response to degarelix after resistance to luteinizing hormone-releasing hormone agonist therapy for metastatic prostate cancer. Anti-cancer drugs 2011;22:299-302.

16. Casey R, Abramovitch A, Andreou C, et al. Inadequate testosterone suppression in prostate cancer patients failing on GnRH agonists: preliminary data from the DELAY study. Canadian Urological Association Meeting, Banff 2012;Poster.

17. Borsellino N, Mauro ML, Nicastro R, et al. Pattern of progression during castration with GnRH agonists (A) and rescue with GnRH antagonist degarelix (D) in patients (PTS) with metastatic prostate cancer (MPC). Journal of Clinical Oncology 2014;32:e16072-e.

18. Klotz L, Drachenberg D, Singal R, et al. An open-label, phase 2 trial of bicalutamide dose escalation from $50 \mathrm{mg}$ to $150 \mathrm{mg}$ in men with $\mathrm{CAB}$ and castration resistance. A Canadian Urology Research Consortium Study. Prostate cancer and prostatic diseases 2014;17:320-4.

19. Shore ND, Chowdhury S, Villers A, et al. Efficacy and safety of enzalutamide versus bicalutamide for patients with metastatic prostate cancer (TERRAIN): a randomised, double-blind, phase 2 study. The Lancet. Oncology 2016;17:153-63.

20. Smith MR, Saad F, Chowdhury S, et al. Apalutamide Treatment and Metastasis-free Survival in Prostate Cancer. The New England journal of medicine 2018;378:1408-18.

21. Hussain M, Fizazi K, Saad F, et al. Enzalutamide in Men with Nonmetastatic, CastrationResistant Prostate Cancer. The New England journal of medicine 2018;378:2465-74.

22. Crawford ED, Schally AV, Pinthus JH, et al. The potential role of follicle-stimulating hormone in the cardiovascular, metabolic, skeletal, and cognitive effects associated with androgen deprivation therapy. Urologic oncology 2017;35:183-91.

23. Klotz L, O'Callaghan C, Ding K, et al. Nadir testosterone within first year of androgendeprivation therapy (ADT) predicts for time to castration-resistant progression: a secondary analysis of the PR-7 trial of intermittent versus continuous ADT. Journal of clinical oncology : official journal of the American Society of Clinical Oncology 2015;33:1151-6.

24. Beer TM, Garzotto M, Eilers KM, et al. Targeting FSH in androgen-independent prostate cancer: abarelix for prostate cancer progressing after orchiectomy. Urology 2004;63:3427.

25. de la Rosette J, Davis R, 3rd, Frankel D, et al. Efficacy and safety of androgen deprivation therapy after switching from monthly leuprolide to monthly degarelix in patients with prostate cancer. International journal of clinical practice 2011;65:559-66.

26. Beer TM, Garzotto M, Eilers KM, et al. Phase II study of abarelix depot for androgen independent prostate cancer progression during gonadotropin-releasing hormone agonist therapy. The Journal of urology 2003;169:1738-41.

27. Crawford ED, Tombal B, Keane T, et al. FSH suppression and tumour control in patients with prostate cancer during androgen deprivation with a GnRH agonist or antagonist. Scandinavian journal of urology 2019:1-9. 
28. Siraj A, Desestret V, Antoine M, et al. Expression of follicle-stimulating hormone receptor by the vascular endothelium in tumor metastases. BMC cancer 2013;13:246.

29. Hoare D, Skinner TA, Black A, et al. Serum follicle-stimulating hormone levels predict time to development of castration-resistant prostate cancer. Canadian Urological Association journal = Journal de l'Association des urologues du Canada 2015;9:122-7.

30. Sartor AO, Tangen CM, Hussain MH, et al. Antiandrogen withdrawal in castraterefractory prostate cancer: a Southwest Oncology Group trial (SWOG 9426). Cancer 2008;112:2393-400. 
Figures and Tables

Fig. 1. Proportion (\%) of patients with any prostate-specific antigen (PSA) response among included studies and a pooled PSA response rate by random effects meta-analysis.

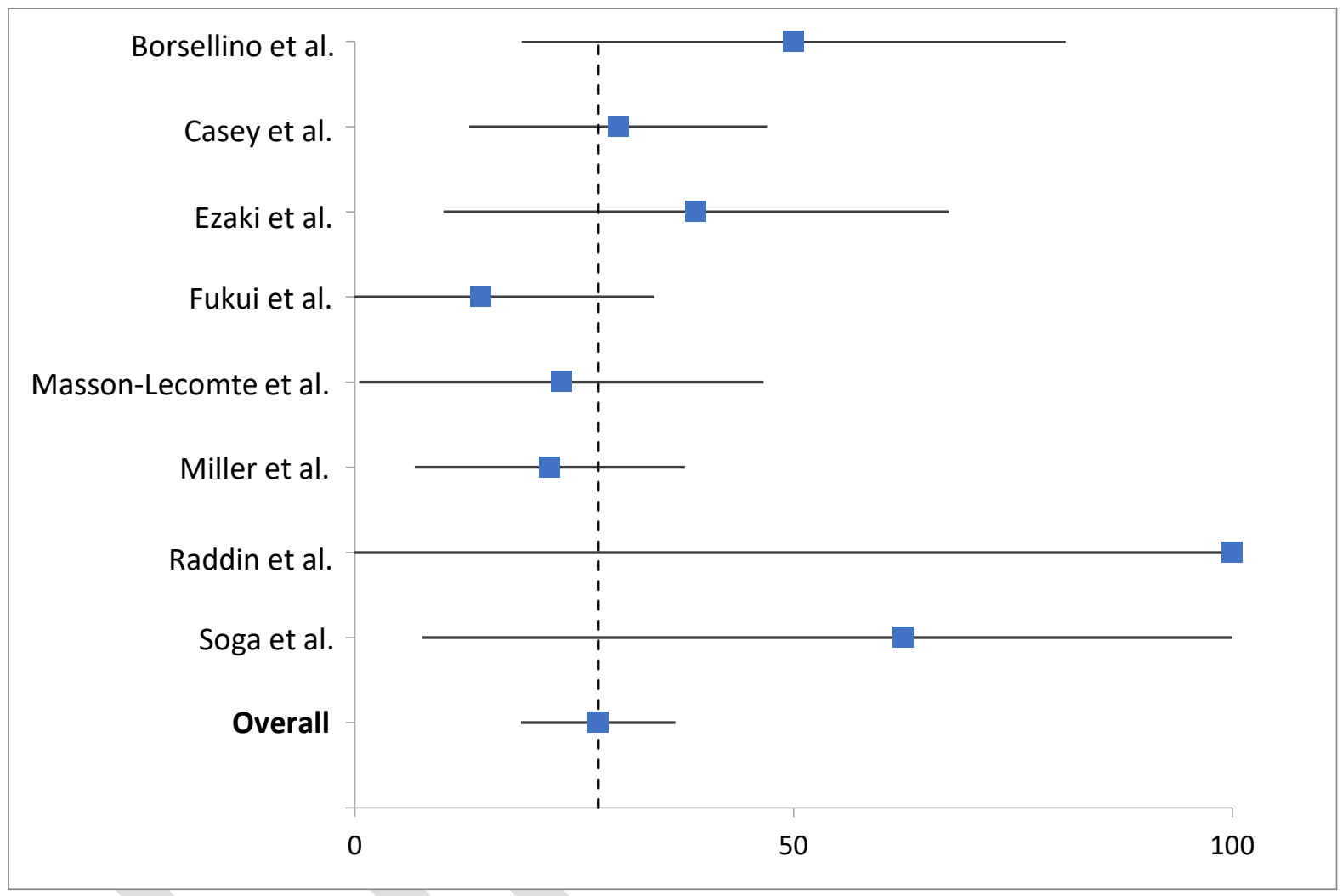




\begin{tabular}{|c|c|c|c|c|c|c|}
\hline Study & $\begin{array}{l}\text { Type of } \\
\text { study }\end{array}$ & Year & Country & $\begin{array}{c}\text { Number } \\
\text { of } \\
\text { patients }\end{array}$ & Clinical stage & $\begin{array}{c}\text { Gleason } \\
\text { score at } \\
\text { diagnosis }\end{array}$ \\
\hline $\begin{array}{l}\text { Borsellino et } \\
\mathrm{al}^{17}\end{array}$ & $\begin{array}{c}\text { Prospective } \\
\text { observational } \\
\text { study }\end{array}$ & 2014 & Italy & 20 & $\begin{array}{l}\text { N1 or M1 } \\
(n=20)\end{array}$ & NR \\
\hline Casey et al ${ }^{16}$ & $\begin{array}{c}\text { Prospective } \\
\text { observational } \\
\text { study }\end{array}$ & 2012 & Canada & 40 & NR & NR \\
\hline Ezaki et $\mathrm{al}^{10}$ & $\begin{array}{c}\text { Retrospective } \\
\text { observational } \\
\text { study }\end{array}$ & 2015 & Japan & 18 & $\begin{array}{c}\text { N0/M0 }(n=9) \\
\text { N1 or M1 } \\
(n=9)\end{array}$ & $\begin{array}{l}\leq 6(n=3) \\
>6(n=15)\end{array}$ \\
\hline Fukui et al ${ }^{11}$ & $\begin{array}{c}\text { Prospective } \\
\text { observational } \\
\text { study }\end{array}$ & 2016 & Japan & 14 & $\begin{array}{c}\text { N0/M0 }(n=7) \\
\text { N1 or M1 } \\
(n=7)\end{array}$ & $\begin{array}{l}\leq 6(n=2) \\
>6(n=9)\end{array}$ \\
\hline $\begin{array}{l}\text { Masson- } \\
\text { Lecomte et } \\
\mathrm{al}^{12}\end{array}$ & $\begin{array}{c}\text { Retrospective } \\
\text { observational } \\
\text { study }\end{array}$ & 2013 & France & 17 & $\begin{array}{c}\text { N0/M0 }(n=4) \\
\text { N1 or M1 } \\
(n=13)\end{array}$ & $\begin{array}{l}\text { Mean } \pm \text { SD } \\
8 \pm 1\end{array}$ \\
\hline Miller et $\mathrm{al}^{14}$ & $\begin{array}{c}\text { Prospective } \\
\text { observational } \\
\text { study }\end{array}$ & 2015 & Germany & $\begin{array}{c}24 \\
\text { (Cohort } \\
\text { I) } \\
12 \\
\text { (Cohort } \\
\text { II) }\end{array}$ & $\begin{array}{c}\text { Cohort I : M0 } \\
(\mathrm{n}=17), \mathrm{M} 1 \\
(\mathrm{n}=7) \\
\text { Cohort II : M0 } \\
(\mathrm{n}=7), \mathrm{M} 1 \\
(\mathrm{n}=5)\end{array}$ & $\begin{array}{c}\text { Cohort I: } \leq 6 \\
(n=5)>6 \\
(n=19) \\
\text { Cohort II: } \leq 6 \\
(n=5),>6 \\
(n=7)\end{array}$ \\
\hline Raddin et $\mathrm{al}^{15}$ & Case report & 2011 & U.S. & 2 & $\begin{array}{c}\text { Case } 1: \text { M1 } \\
\text { Case } 2: \text { N1M0 }\end{array}$ & $\begin{array}{l}\text { Case 1: } 9 \\
\text { Case 2: } 7\end{array}$ \\
\hline Soga et $\mathrm{al}^{13}$ & $\begin{array}{c}\text { Prospective } \\
\text { observational } \\
\text { study }\end{array}$ & 2015 & Japan & 8 & $\begin{array}{c}\text { N0/M0 }(n=2) \\
\text { N1 or M1 } \\
(n=6)\end{array}$ & $\begin{array}{l}\leq 6(\mathrm{n}=1) \\
>6(\mathrm{n}=7)\end{array}$ \\
\hline
\end{tabular}

NR: not reported; SD: standard deviation. 


\begin{tabular}{|c|c|c|c|c|}
\hline Study & $\begin{array}{l}\text { Age at the } \\
\text { switch }\end{array}$ & $\begin{array}{l}\text { PSA level at the } \\
\text { switch (ng/mL) }\end{array}$ & $\begin{array}{l}\text { Testosterone level } \\
\text { at the switch } \\
\text { (ng/mL) }\end{array}$ & $\begin{array}{c}\text { Duration on } \\
\text { agonist } \\
\text { before switch } \\
\text { (months) }\end{array}$ \\
\hline $\begin{array}{l}\text { Borsellino } \\
\text { et } \mathrm{al}^{17}\end{array}$ & $\begin{array}{l}\text { Median (range), } \\
77.5 \text { (65-86) }\end{array}$ & NR & $\begin{aligned}<0.5(\mathrm{n}=7) \\
0.2<\mathrm{T}<0.5(\mathrm{n}=13)\end{aligned}$ & $\mathrm{NR}$ \\
\hline $\begin{array}{l}\text { Casey et } \\
\mathrm{al}^{16}\end{array}$ & $\begin{array}{l}\text { Median (range), } \\
81 \text { (63-93) }\end{array}$ & $\begin{array}{c}\text { Mean (range), } \\
17.7(1.3-141) \\
\end{array}$ & $\begin{array}{c}\text { Mean (range), } \\
0.288(0.029-3.58) \\
\end{array}$ & NR \\
\hline $\begin{array}{l}\text { Ezaki et } \\
\mathrm{al}^{10}\end{array}$ & $\begin{array}{l}\text { Median (range), } \\
74 \text { (61-91) }\end{array}$ & $\begin{array}{l}\text { Median (range), } \\
7.9(0.37-1709)\end{array}$ & $\begin{array}{c}\text { Median (range), } \\
0.17(<0.08-0.81)\end{array}$ & $\begin{array}{c}\text { Median (range), } \\
35.5 \text { (9-177) }\end{array}$ \\
\hline $\begin{array}{l}\text { Fukui et } \\
\mathrm{al}^{11}\end{array}$ & $\begin{array}{l}\text { Mean } \pm \text { SD } \\
81.4 \pm 4.3\end{array}$ & $\begin{array}{l}\text { Mean } \pm \text { SD } \\
28.6 \pm 35.0\end{array}$ & $<0.03$ & $\begin{array}{c}\text { Mean } \pm \text { SD } \\
79.6 \pm 63.9\end{array}$ \\
\hline $\begin{array}{l}\text { Masson- } \\
\text { Lecomte } \\
\text { et } \mathrm{al}^{12}\end{array}$ & $\begin{array}{c}\text { Mean } \pm \text { SD } \\
7 \pm 9 \\
\text { (at diagnosis) }\end{array}$ & $\begin{array}{l}\text { Mean } \pm \text { SD, } \\
34.33 \pm 50.32\end{array}$ & $\begin{array}{l}\text { Mean } \pm \text { SD } \\
0.21 \pm 0.13\end{array}$ & $\begin{array}{c}\text { Mean } \pm \text { SD } \\
42 \pm 37\end{array}$ \\
\hline $\begin{array}{l}\text { Miller et } \\
\mathrm{al}^{14}\end{array}$ & $\begin{array}{l}\text { Cohort I: Median } \\
\text { (range), } 73.5 \\
\text { (52-85) } \\
\text { Cohort II: } \\
\text { Median (range), } \\
75 \text { (72-88) }\end{array}$ & 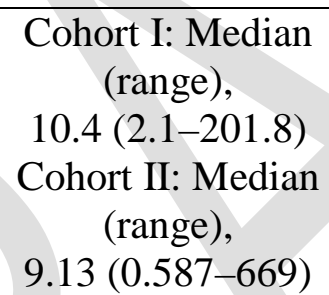 & $\begin{array}{c}\begin{array}{c}\text { Cohort I: Median } \\
\text { (range), }\end{array} \\
0.085 \text { (0.015-1.00) } \\
\text { Cohort II: Median } \\
\text { (range) } \\
0.075 \text { (0.05-1.44) }\end{array}$ & $\geq 12$ \\
\hline $\begin{array}{l}\text { Raddin et } \\
\mathrm{al}^{15}\end{array}$ & $\begin{array}{l}\text { Case 1: } 64 \\
\text { Case 2: } 45\end{array}$ & $\begin{array}{l}\text { Case 1: } 0.5 \\
\text { Case 2: } 58\end{array}$ & $\begin{array}{l}\text { Case } 1: 2.08 \\
\text { Case 2: } 0.43\end{array}$ & $\begin{array}{l}\text { Case 1: } 15 \\
\text { Case 2: } 4\end{array}$ \\
\hline Soga et $\mathrm{al}^{13}$ & $\begin{array}{c}\text { Mean } \pm \text { SD } \\
72.7 \pm 4.5 \\
(64-80)\end{array}$ & NR & $0.2 \leq \mathrm{T}<0.5$ & NR \\
\hline
\end{tabular}

NR: not reported; PSA: prostate-specific antigen; SD: standard deviation. 


\begin{tabular}{|l|c|c|c|c|c|}
\hline Table 3. Summary of prostate-specific antigen (PSA) responses among included studies \\
\hline Study & $\begin{array}{c}\text { Sample } \\
\text { size }\end{array}$ & $\begin{array}{c}\text { Any PSA } \\
\text { response }\end{array}$ & $\begin{array}{c}\text { PSA } \\
\text { response } \\
>\mathbf{1 0 \%} \\
\text { decrease }\end{array}$ & $\begin{array}{c}\text { PSA } \\
\text { response } \\
>\mathbf{3 0 \%} \\
\text { decrease }\end{array}$ & $\begin{array}{c}\text { PSA } \\
\text { response } \\
>\mathbf{5 0 \%} \\
\text { decrease }\end{array}$ \\
\hline Borsellino et al $^{17}$ & 20 & 10 & 8 & 0 & 0 \\
\hline Casey et al $^{16}$ & 40 & 12 & 5 & 3 & 3 \\
\hline Ezaki et al $^{10}$ & 18 & 7 & 5 & 5 & 3 \\
\hline Fukui et al $^{11}$ & 14 & 2 & 1 & 0 & 0 \\
\hline Masson-Lecomte et al $^{12}$ & 17 & 4 & 3 & 2 & 1 \\
\hline Miller et al $^{14}$ & 36 & 8 & 4 & 2 & 2 \\
\hline Raddin et al $^{15}$ & 2 & 2 & 2 & 2 & 2 \\
\hline Soga et al & & 2 & 2 & 2 & 2 \\
\hline Overall $^{13}$ & 8 & 5 & $\mathbf{3 0}$ & $\mathbf{1 6}$ & $\mathbf{1 3}$ \\
\hline
\end{tabular}

A PSA response was defined as a change in PSA from the baseline value at the time of switch from GnRH agonist to degarelix that is either stable ( $\leq 10 \%$ variation) or decreasing. 


\section{Supplementary Figures and Tables}

Supplementary Fig. 1. Preferred Reporting Items for Systematic Reviews and Meta-Analyses (PRISMA) flow diagram outlining the literature search and the included and excluded studies. PSA: prostate-specific antigen.

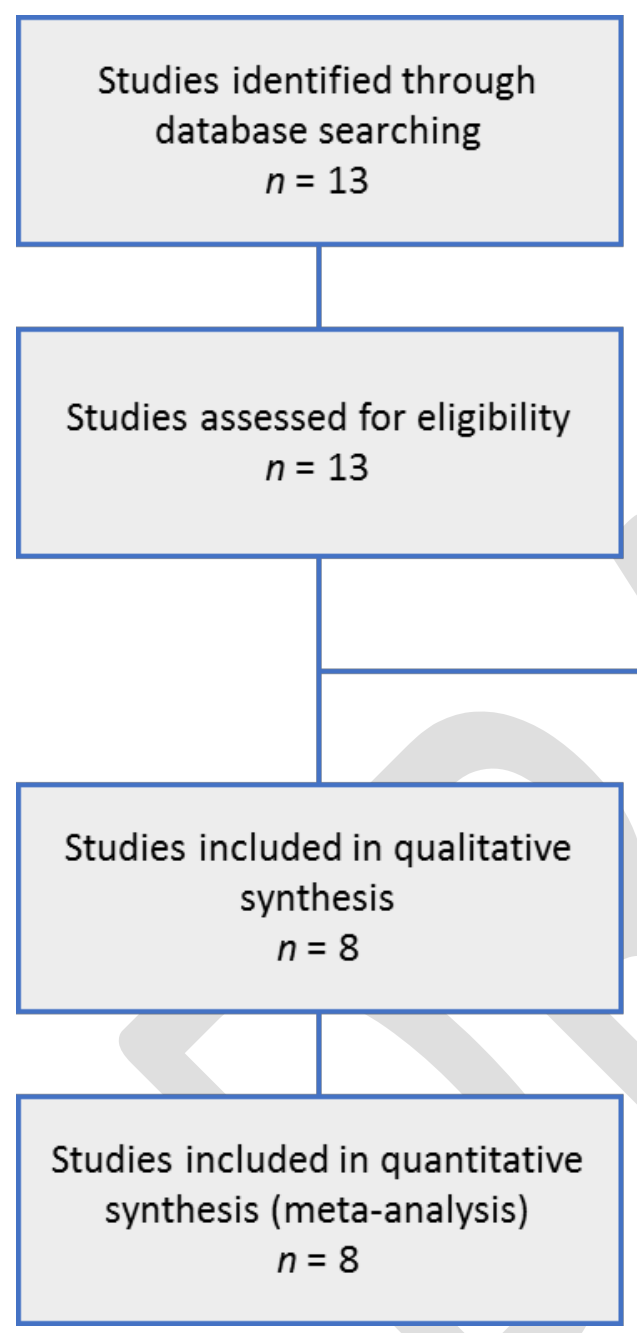

Excluded after full-text review:

Switch not at PSA progression ( $n=2)$ Other $\mathrm{GnRH}$ antagonist (Abarelix) $(n=2)$

Case report with 1 month follow-up $(n=1)$ 


\begin{tabular}{|c|c|c|c|c|}
\hline \multicolumn{5}{|c|}{$\begin{array}{l}\text { Supplementary Table 1. Proportion of patients with any prostate-specific antigen (PSA) } \\
\text { response among included studies and a pooled PSA response rate by random effects meta- } \\
\text { analysis and a } I^{2} \text { value for assessment of heterogeneity }\end{array}$} \\
\hline Study & $\begin{array}{l}\text { Sample } \\
\text { size }\end{array}$ & $\begin{array}{l}\text { Outcome } \\
\text { (events) }\end{array}$ & $\begin{array}{c}\text { Proportion } \\
\text { (95\% confidence } \\
\text { interval) }\end{array}$ & $\begin{array}{l}\text { Heterogeneity } \\
\qquad\left(\mathbf{I}^{2}\right)\end{array}$ \\
\hline Borsellino et al $^{17}$ & 20 & 10 & $50(19-81)$ & \\
\hline Casey et $\mathrm{al}^{16}$ & 40 & 12 & $30(13-47)$ & \\
\hline Ezaki et $\mathrm{al}^{10}$ & 18 & 7 & $39(10-68)$ & \\
\hline Fukui et $\mathrm{al}^{11}$ & 14 & 2 & $14(0-34)$ & \\
\hline Masson-Lecomte et al ${ }^{12}$ & 17 & 4 & $24(0-47)$ & \\
\hline Miller et $\mathrm{al}^{14}$ & 36 & 8 & $22(7-38)$ & \\
\hline Raddin et $\mathrm{al}^{15}$ & 2 & 2 & $100(-38-239)$ & \\
\hline Soga et al ${ }^{13}$ & 8 & 5 & $63(8-117)$ & \\
\hline Overall & 155 & 50 & $27.7(18.9-36.5)$ & $7.90 \%$ \\
\hline
\end{tabular}

Disclosure of potential conflicts of interest: NF participates in clinical trials for Astellas, Baverian, Nordic, Ferring, Janssen, Medivation, Nucleix, Progenics, Sanofi and Spectracure AB. N.F. reports personal fees as an advisor for Abbvie, Amgen, Astellas, Bayer, Ferring, Janssen, Sanofi, and Hybridyne Health. P.T. reports research funding from Innocrin Pharmaceuticals and Janssen as well as personal fees as an advisor for Ferring Pharmaceuticals, Sanofi, Astellas Pharma and AbbVie. P.T. participates in clinical trials for Roche, Janssen, Merck, MedImmune, Progenics, AstraZeneca and Bayer. There are no financial conflicts of interest for the other authors. 